\title{
Taxonomic study of freshwater Green Algae in relation to water quality of Tehsil Landikotal, Khyber Agency, Pakistan
}

\section{Haroon Khan ${ }^{1}$, Muhammad Fiaz, Sahib Khan ${ }^{1}$, Fida Hussainn ${ }^{2,3}$, Syed Zahir Shah ${ }^{4}$, Muzammil Shah ${ }^{4}$, Muhammad Shuaib ${ }^{5^{*}}$, Muhammad Saeed $^{3}$, Faisal Raza ${ }^{6}$ and Muhammad Khan Laghari ${ }^{7}$}

1. Department of Botany, Hazara University Mansehra-Pakistan

2. School of Resources, Environmental \& Chemical Engineering and Key Laboratory of Poyang Lake Environment and Resource Utilization, Nanchang University, Nanchang,330000-China

3. Department of Botany, Qurtuba University of Science and Information Technology, Peshawar 25100, KPK-

Pakistan

4. Department of Botany, Islamia College Peshawar, 25100-Pakistan

5. School of Ecology and Environmental Science, Yunnan University, North Cuihu road, Kunming, Yunnan, 650091, PR-China

6. China Pharmaceutical University, Nanjing-China

7. Pakistan Museum of Natural History, Islamabad-Pakistan

*Corresponding author's email: zeyadz44@yahoo.com

Citation

Haroon Khan, Muhammad Fiaz, Sahib Khan, Fida Hussain, Syed Zahir Shah, Muzammil Shah, Muhammad Shuaib, Muhammad Saeed, Faisal Raza and Muhammad Khan Laghari. Taxonomic study of freshwater Green Algae in relation to water quality of Tehsil Landikotal, Khyber Agency, Pakistan. Pure and Applied Biology. Vol. 6, Issue 4, pp1328-1334. http://dx.doi.org/10.19045/bspab.2017.600142

\begin{tabular}{lllll}
\hline \hline Received: & 20/06/2017 & Revised: 13/10/2017 & Accepted: 17/10/2017 & Online First: 20/10/2017 \\
\hline
\end{tabular}

\section{Abstract}

The quality of water bodies determines the algal diversity in the specific region, Tehsil Landikotal the primary seepage bowl of stream Kabul is broadly known for ripe land, the range of mountains, natural water stream and for, it's biological resource. Current research work is the result show the record of green algae diversity in the local area. Sum 33 species of green algae (Class Chlorophyceae) belonging to 11 orders, 17 families and 28 genera have been identified from freshwater bodies of 6 major areas of Tehsil Landi Kotal Khyber Agency, Pakistan. Among the identified 41 species, the most prevalent genera were Cosmarium with 5 species (12.5\%) followed by Ulothrix with 3 species (8\%). Among the other genera, Oedogonium is represented by 2 species, Microspora 2 species, Tetraspora 2 species, Gleocystis 2 species, Tetraedron 2 species, and Pedistrum 2 species representing (5\%) each. The differing qualities of green algae in the present zone demonstrate that a considerable measure of work is required with respect to green algae and normal for their territory.

Keywords: Water quality, Green algae, Phsico-chemical characteristics

\section{Introduction}

Khyber Agency is a Federally Administered

Tribal Area of Pakistan. Which is located in the north of Pakistan. It has a border with Afghanistan, Peshawar city, Kurram, and Orakzai Agencies. The entire area of the 
Khyber Agency is 2,576 Sq Km. The Khyber Agency consists of three Tehsils, LandiKotal, Jamrud, and Bara. LandiKotal is located at $34^{\circ} 6^{\prime} 4 \mathrm{~N} 71^{\circ} 8^{\prime} 44 \mathrm{E}$ and lies on the Khyber Pass in the Khyber Agency at 1,072 metres above sea level, it is the headquarters of the Agency administration of Khyber and it is on the way across the mountains to the city of Peshawar LandiKotal Tehsil consist four major territories Tirah, Khyber, LandiKotal, and Shalmans, The Shalmans include Loy Shalman and Kam Shalman [1].

The famous River Kabul is 700 kilometer long river that emerges in the Sanglakh range of the Hindukush mountain in Afghanistan and run through these mountains enter to Loy Shalman area of Landikotal Khyber Agency which flow further and join the river Indus Attock Pakistan, beside this there are natural stream and water channel which is originated from different mountains such Ghar water stream in Ali Masjid, natural stream of Landi Khana Torkham, some natural water channel among the mountain of Muktarkhel, Ashkel, Perokhel and Kam Shalman which flow throughout year are the natural reservoir of water. LandiKotal has a barren and rocky mountainous landscape. The area mostly consists of hilly tracks, mountains and narrow strips of valleys. It is the meeting place of high ranges of the mountain such as the Koh-e-Safaid, and outcome of the mighty Hindukush Mountains. The smaller part consists of the plain area which mainly consists of loamy sand and loamy clay soil texture. The area is entirely fertile and can produce good crops, but due to suffering fall, some fall some of its areas is barren, some areas of the cultivation are rainfalls (Barani in Urdu) and under the good condition of weather and plenty, rainfall gives very good yield to the growth of wheat, maize, and vegetable. A small part of this area is plain and fertile where a variety of fruit plants are grown-up by local people for their own use, many different fruits also grown-up by people for their making money $[1,2]$.

Green algae are monoecious, gathering of life form having no sterile cells around their sex organs and are not genuine embryophyte [3]. Green growth is the essential makers in any normal and amphibian environment [4]. Yet, on the opposite side, they are poisonous weeds too in specific circumstances. For instance, in dormant or moderate moving waters or in the water bodies with more supplements compost, keep running off and with wastewater release and mechanical effluents, green growth develops quickly to cause water sprouts. They cause the demise of the widely varied vegetation happening in the pervaded water bodies. Green growth is generally in their events that are available practically in each soggy environment, including soil consistently [4]. The water bodies going through the city and huge towns are especially inclined to the overwhelming impacts of eutrophication because of the huge expansion of supplements as sewage waters. The types of green growth causing water sprout must be recognized and brought up for maintaining a strategic distance from the lethal impact of water blossom on the gainful fauna of the water body. Many reviews have recognized green growth from an assortment of soils and new water environments [5]. More than 500 genera and 8000 types of green growth are found and substantial numbers are yet to be found. Spirogyra is outstanding green growth and has adjusted chloroplast. Some green growth is duplicating abiogenetically and also sexually. Green growth has a rotation of era in which gametophyte deliver sporophyte and the other way around [6].

\section{Materials and Methods}

The research mainly concerned with a taxonomy of green algae including their identification, classification, and distribution from a different place of Tehsil Landikotal, Khyber Agency. Total 6 selected places of 
Tehsil LandiKotal is selected for the current research. It includes Loy Shalman Yakha Cheena, Ashkhel, Mukhterkhel, Kam
Shalman, Torkham Landikhana and Ali Masjid shown in (Figure 1).

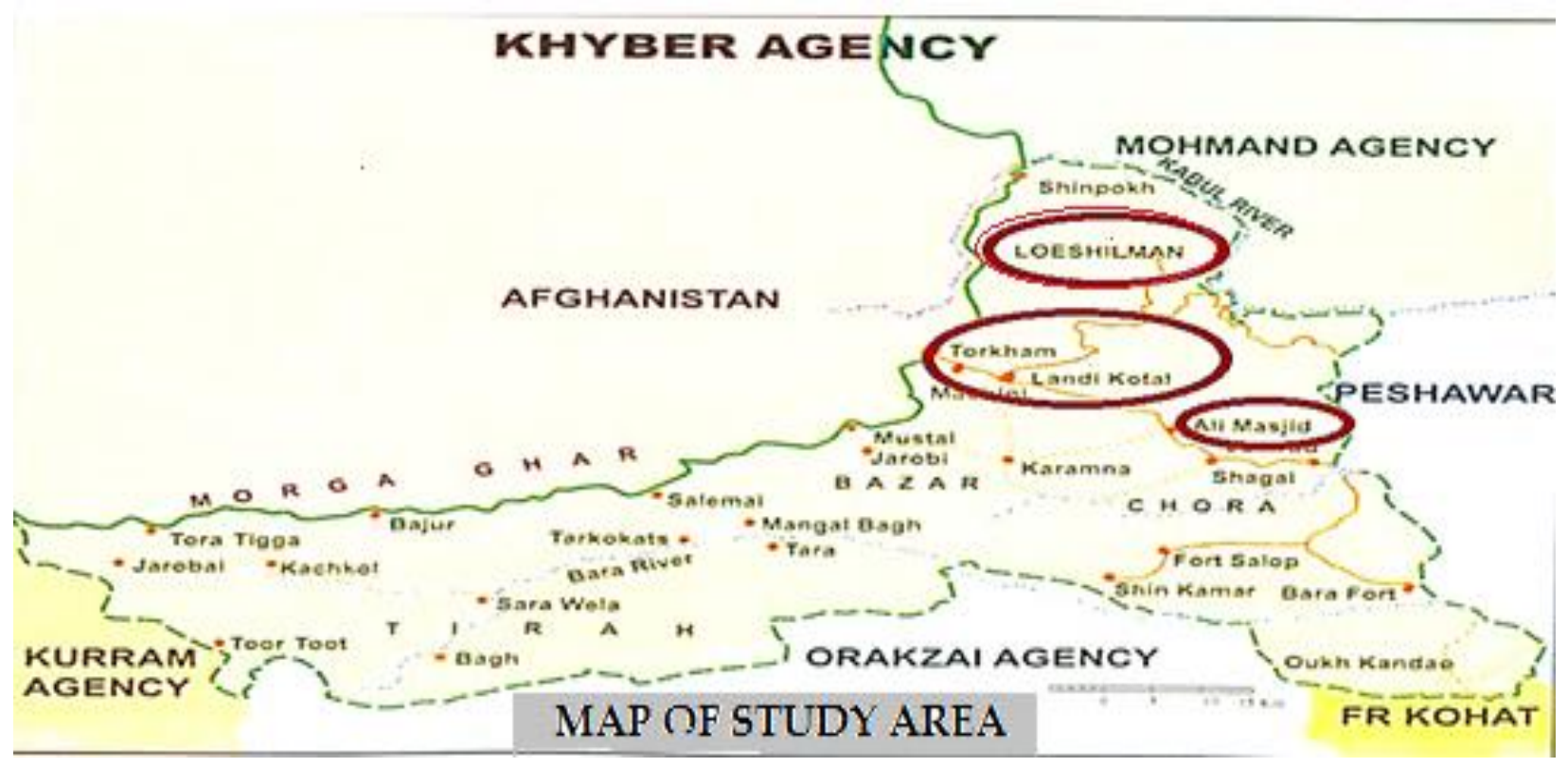

Figure 1. Represents the map of study area

Samples of algae were collected from research area. The collection was simply hand-picking from different freshwater reservoir such is standing, running water. The $\mathrm{PH}$ of water and the air temperature was recorded on the spot. The algae water sample brought to the laboratory in a plastic bottle and were assorted in $4 \%$ formalin solution in specimen tubes for preservation. Slides were made each simple. The drop of each sample was put out with help of micropipette from bottle put the drop on the slide and covered with slip. Identification was made using objective $10^{\mathrm{x}}, 20^{\mathrm{x},} 40^{\mathrm{x}}$ under microscope $\mathrm{BH}$ 2 Olympus made by Japan Usually we used $10^{\mathrm{x}}, 20^{\mathrm{x}}$ eyes piece, the eyepiece was fixed with a lined ocular micrometer. The identification of species was made with the help of existing literature [8-11].

The algal water samples from the study areas were brought to PCSIR laboratory Peshawar, where standard methods for the examination of water and wastewater $21^{\text {st }}$ edition, 2005 used for analysis of chemical and physical properties which are found in the algal flora.

\section{Results}

Forty-one species of Class Chlorophyceae (green algae) were identified from a collected sample of Tehsil Landikotal Khyber Agency. The identified species were sorted out in 11 orders, 17 families and 28 genera. The most widely recognized genus is Cosmarium, having 5 spp.make $12.11 \%$, of the entire spp. of Class Chlorophyceae, the other genera are Ulothrix with 3 species (8.10\%) Oedogonium with 2 species (5.40\%) Microspora with 2 species $(5.40 \%)$ Tetraspora with 2 species (5.40\%) Tetreadron with 2 species $(5.40 \%)$ Gleocystis with 3 species $(8.10 \%)$ Pediastrum with 2 species $(5.40 \%)$. The rare genera occurring Phacotus, Wislouchiells, Pandorina, Eudorina, Haematococcuss, Sphaerocystis, Chlamydomonas, Chladophora, Kirchneriella, Oocystis, Ankistrodesmus, Chlorella, Scenedesmus, Zygnema, Closterium, Spirogyra, 
Hormidium, Stigeoelonium and Pedinopera with 1 species $(2.85 \%)$ each (Figure 2$)$. The most prevalent families were Desmidiaceae with 6 species followed by Oocystaceae with 5 species. The ratio of $\mathrm{PH}$ in water in the different area is different from the other range from 7.36-8.20, although the range of water temperature was $17 \mathrm{c}-18 \mathrm{c}$, the total spp. Diversity laterally through their physiochemical analysis accessible below.

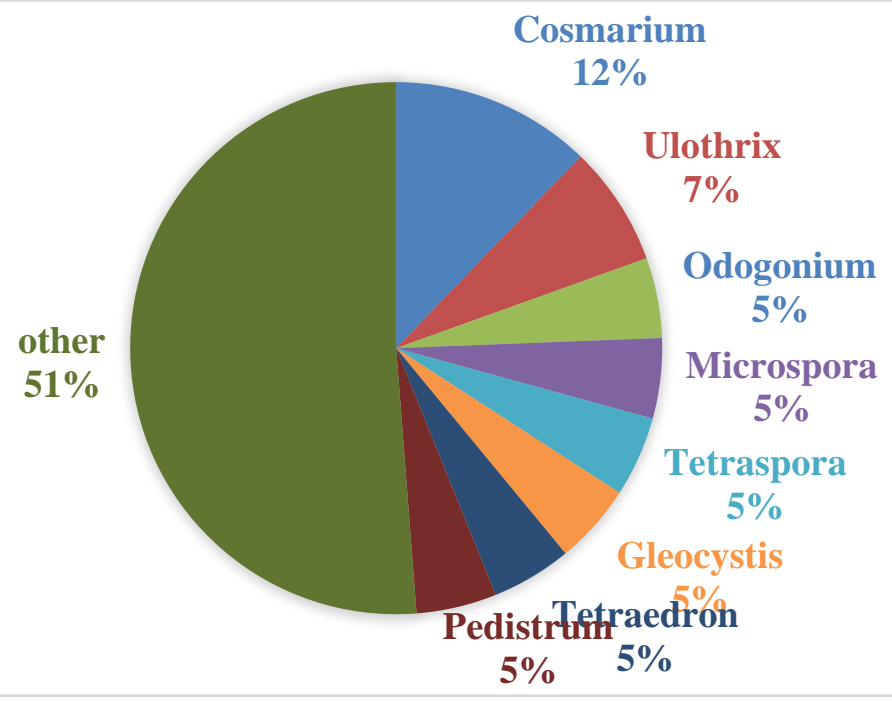

Figure 2. Algal diversity of different site of tehsil LandiKotal

\section{Khyber Ali Masjid}

The total speciesrecorded from the various site of Ali Masjid:

Oedogonium decipiensvar dissimile, Odegonium reinschii, Spirogyra, Gloeocystis ampla, Gloeocystis gigas, Eudorina elegans, Ulothrix zoneta, Hormidium klebsii, Pandorinamorum, Cosmmarium suspraspeciosum, and Cosmmarium punctulata

The PH of water in Ali Masjid is 7.90 conductivity is $480 \mu \mathrm{S} / \mathrm{cm}$, TDS is 400.00 $\mathrm{mg} / \mathrm{L}$, TSS is $7.00 \mathrm{mg} / \mathrm{L}$, Total hardness as $\mathrm{CaCO} 3$ is $328.38 \mathrm{mg} / \mathrm{L}$, Calcium as $\mathrm{CaCo} 3$ $200 \mathrm{Mg} / \mathrm{L}$, Magnesium as $\mathrm{MgCo} 3$ $136.27 \mathrm{mg} / \mathrm{L}$, Total Alkalinity as $\mathrm{CaCo} 3$ $300.2 \mathrm{mg} / \mathrm{L}$, P-Alkalinity as $\mathrm{CaCo} 3$ is NIL, Chloride as CL-1 is $40.54 \mathrm{mg} / \mathrm{L}$, Sulfate as $\mathrm{SO} 4-2$ is $47.00 \mathrm{mg} / \mathrm{L}$, Sodium as $\mathrm{Na}+$ ! is $30.00 \mathrm{mg} / \mathrm{L}$, Potassium as $\mathrm{K}+! 1.90 \mathrm{mg} / \mathrm{L}$.

\section{Torkham Landikhana}

The total species recorded from various site Torkham landikhana
Scenedesmus bijugatus, Ankistrodesmus falcatus,

The PH of water in Torkham Landikhana is 7.60. Conductivity is $553.33 \mu \mathrm{S} / \mathrm{cm}$, TDS is $350.23 \mathrm{mg} / \mathrm{L}$, TSS is $6.00 \mathrm{mg} / \mathrm{L}$, Total hardness as $\mathrm{CaCO} 3$ is $280.38 \mathrm{mg} / \mathrm{L}$, Calcium as a $\mathrm{CaCo} 3148.29 \mathrm{mg} / \mathrm{L}$ Magnesium as $\mathrm{MgCo} 390 \mathrm{mg} / \mathrm{L}$,Total Alkalinity as $\mathrm{CaCo} 3$ $300.2 \mathrm{mg} / \mathrm{L}$, P-Alkalinity as $\mathrm{CaCo} 3$ is NIL, Chloride as CL-1 is $30.0 \mathrm{mg} / \mathrm{L}$, Sulfate as SO4-2 $21.00 \mathrm{mg} / \mathrm{L}$, Sodium as $\mathrm{Na}+$ ! is $22.10 \mathrm{mg} / \mathrm{L}$, Potassium as K+! $1.90 \mathrm{mg} / \mathrm{L}$.

\section{Mukhter Khel}

The total species recorded from MukhterKhel Sphaerocystis schroeteri, Pedinopera grcenulosa, Tetraedron vulgarea and Tetraedron muticum

The PH of water in Mukhter Khel is 7.80, conductivity is $310.00 \mu \mathrm{S} / \mathrm{cm}$, TDS is 310 $\mathrm{mg} / \mathrm{L} \mathrm{TSS}$ is $7.00 \mathrm{mg} / \mathrm{L}$, Total hardness as $\mathrm{CaCO} 3$ is $240.48 \mathrm{mg} / \mathrm{L}$, Calcium as $\mathrm{CaCo} 3$ 120.24 Magnesium as $\mathrm{MgCo} 3120.24$ Total Alkalinity as $\mathrm{CaCo} 3 \quad 151.20 \mathrm{mg} / \mathrm{L}, \quad \mathrm{P}-$ 
Alkalinity as $\mathrm{CaCo} 3$ is NIL, Chloride as CL1 is $28.62 \mathrm{mg} / \mathrm{L}$, Sulfate as SO4-2 is 32.4 Sodium as $\mathrm{Na}+$ ! is $19.00 \mathrm{mg} / \mathrm{L}$, Potassium as $\mathrm{K}+! 1.60 \mathrm{mg} / \mathrm{L}$.

\section{Ashkhel}

The total species recorded from various site of Ashkhel

Pediastrum braunii, Pediastrum integrum, Chlorella vulgar, Chladophora glumerata, Cosmarium subcostatum, Cosmarium Granatum and Ulothrix subconstratus.

The PH of water in Ashkhel is 7.80, Conductivity is $370.00 \mu \mathrm{S} / \mathrm{cm}$, TDS is 300 $\mathrm{mg} / \mathrm{L}$, TSS is $8.00 \mathrm{mg} / \mathrm{L}$, Total hardness as $\mathrm{CaCO} 3$ is $264.48 \mathrm{mg} / \mathrm{L}$, Magnesium as MgCo3 $156.31 \mathrm{mg} / \mathrm{L}$, Total Alkalinity as $\mathrm{CaCo} 3208.8 \mathrm{mg} / \mathrm{L}$, P Alkalinity as $\mathrm{CaCo} 3$ is NIL, Chloride as CL-1 is $40.55 \mathrm{mg} / \mathrm{L}$, Sulfate as $\mathrm{SO} 4-2$ is $54.6 \mathrm{mg} / \mathrm{L}$, Sodium as $\mathrm{Na}+$ ! is $23.00 \mathrm{mg} / \mathrm{L}$, Potassium as $\mathrm{K}+! 3.20 \mathrm{mg} / \mathrm{L}$.

\section{Kam Shelman}

The total species recorded from various site of Kam Shelman

Wislouchiells planetonica, Uothrixviriblis, Zygnema chalybeospermum, Closterium acerosum, var elongatum, Oocystis natans, Chlamydomonas snowii, Kirchneriella lunaris, Gemiinella ordanataand Stigeoelonium subsecundum.

The PH of water in Kam Shelman is 7.84, Conductivity is $700.00 \mu \mathrm{S} / \mathrm{cm}$, TDS is $473.00 \mathrm{mg} / \mathrm{L}$, TSS is $7.66 \mathrm{mg} / \mathrm{L}$, Total hardness as $\mathrm{CaCO} 3$ is $359.38 \mathrm{mg} / \mathrm{L}$, Calcium as $\mathrm{CaCo} 3$ 188.37, Magnesium as $\mathrm{MgCo} 3$ $171.00 \mathrm{mg} / \mathrm{L}$ Total Alkalinity as $\mathrm{CaCo} 3$ $271.20 \mathrm{mg} / \mathrm{L}, \mathrm{P}$ Alkalinity as $\mathrm{CaCo} 3$ is NIL, Chloride as CL-1 is $50.53 \mathrm{mg} / \mathrm{L}$, Sulfate as $\mathrm{SO} 4-2$ is $40.00 \mathrm{mg} / \mathrm{L}$ Sodium as $\mathrm{Na}+$ ! is $52.86 \mathrm{mg} / \mathrm{L}$, Potassium as $\mathrm{K}+! 2.00 \mathrm{mg} / \mathrm{L}$.

\section{Loy Shalman}

The species were recorded from various site of Loy ShalmanYakha Cheena

Haematococcuss lucustaris, Tetraspora lubrica, Tetraspora cylindrical, Microspora stagnorum, Microspora willena and Phacotus lenticularis.
The PH of water in Loy Shelman is 7.20, Conductivity is $1400.00 \mu \mathrm{S} / \mathrm{cm}$, TDS is $925.00 \mathrm{mg} / \mathrm{L}$, TSS is $6.66 \mathrm{mg} / \mathrm{L}$, Total hardness as $\mathrm{CaCO} 3$ is $896.45 \mathrm{mg} / \mathrm{L}$, Magnesium as $\mathrm{MgCo} 3402.13 \mathrm{mg} / \mathrm{L}$ Total Alkalinity as $\mathrm{CaCo} 3270.00 \mathrm{mg} / \mathrm{L}, \quad \mathrm{P}$ Alkalinity as $\mathrm{CaCo} 3$ is NIL, Chloride as CL1 is $47.70 \mathrm{mg} / \mathrm{L}$, Sulfate as SO4-2 is 80.00 $\mathrm{mg} / \mathrm{L}$ Sodium as $\mathrm{Na}+$ ! is $39.80 \mathrm{mg} / \mathrm{L}$, Potassium as $\mathrm{K}+! 3.80 \mathrm{mg} / \mathrm{L}$.

\section{Discussion}

These discoveries are bolstered by the work of [11] who arranged comparable agenda of the freshwater green growth from the Northwest Territories of Canada from 44 studies included 279 waterways. A substantial differing qualities of green growth were found in different water bodies from clean water to contaminated waters, frosty to warm waters, dormant to quick running waters and so on. The gathering comprised of 212 genera and 1577 species. The major algal classes spoken to in the rundown were Bacillariophyceae (761 taxa), the Chlorophyceae (481 taxa), and the Cyanophyceae (173 taxa). Likewise, [12] contemplated morpho-ordered depiction of 73 crisp water green growth having a place with 34 genera, 25families, 17 orders and 09 classes in Kalpani stream and connecting range of region Mardan. Among them, $65.75 \%$ has a place with Chlorophyta and $12.33 \%$ has a place with Cyanophyta.

In another review, 138 Chlorophycean species were recorded. Among these 74 species $(53.6 \%)$ have a place with Chlorococcales. 3\% have a place with Cladophorales and Chaetophorales each. While one animal groups to Sphaeropleales [13]. Moreover, Leghari, [14] chipped away at some crisp water green filamentous green growth from Lakes and Ponds of Sindh and revealed 31 types of the Chlorophyta and Chrysophyta from new waters and Riverin lakes. Zarina et al. [15] revealed 211species of different sorts of blue-green growth from 
unexplored freshwater natural surroundings in Punjab and NWFP of Pakistan and AJK amid 1978-2000. Among them, 88 species are recorded surprisingly from Pakistan. Nostocophyceae with 158 species were observed to be more pervasive than different classes like Chroocophyceae and Oscillatoria.

Similar outcomes from the different new water living spaces algal species are systematically identified and investigated from different parts of Pakistan by [6, 16-19]. Similar outcomes from Karachi in crisp water new water green growth environments uncovered by (Aliya et al. [20] the ordered overview of new water green growth from Multan [21]. An aggregate of 68 blue-green algal species having a place with 29 genera reported from different living space like waterways, streams, lakes, stale water and wastewater archived from area Malakand KPK, Pakistan by [22]. Similar outcomes from Dir lower river Panjkora by [6], explain the various algal species in relations to water qualities in water bodies. The $\mathrm{pH}$ of various water bodies from different crisp water algal natural surroundings, dormant and running water and wastewater bodies clarify. The algal differences were seen in wastewater bodies which are commanded in algal sprouts amid summer seasons by [24].

\section{Conclusions}

Study and research on green algae in the water bodies of Landi Kotal Peshawar is the most overlooked territory of amphibian herbal science. In spite of the fact that Peshawar has numerous waterways, lakes and other crisp water bodies where green growth exists in plenitude. This review explored the green growth of Landi Kotal territory of District Peshawar and found an aggregate of Sum 33 species of green algae (Class Chlorophyceae) belonging to 11 orders, 17 families and 28 genera have been identified from freshwater bodies of 6 major areas of Tehsil Landi Kotal Khyber Agency,
Pakistan. Among the identified 41 species, the most prevalent genera were Cosmarium with 5 species (12.5\%) followed by Ulothrix with 3 species (8\%). Among the other genera,Oedogonium is represented by 2 species, Microspora 2 species, Tetraspora 2 species, Gleocystis 2 species, Tetraedron 2 species and Pedistrum 2 species representing (5\%) each. The differences of green algae in the present region demonstrate that a great deal of work is required with respect to green algae and normal for their living space. Thus further reviews are proposed to be attempted in such manner.

\section{Authors' contributions}

Conceived and designed the experiments: $\mathrm{H}$ Khan, M Fiaz \& S Khan, Performed the fields work and experiments: F Hussain, SZ Shah \& M Shah, Analyzed the data: M Shuaib \& M Saeed, contributed reagents/ materials/ analysis tools: F Raza \& MK Laghari, Wrote the paper: M Shuaib \& F Hussain.

\section{References}

1. Ali K, Gul B, Hussain F, Khan H, Ali M, Ali S, Ali S \& Junaid K (2015). The study of algae: the non-vascular aquatic weeds from various fresh water bodies of Peshawar Pakistan. Pak J Weed Sci Res 21(1): 111-122.

2. Ullah A \& Ullah S (2016). Vascular plant diversity in Landi Kotal Valley, Khyber Agency, Pakistan. FUUAST Journal of Biologyc 1: 6(2).

3. Shameel M (2003). Biodiversity and natural history of algae. J Nat Hist Wildl 2(1): 1-9.

4. Shameel M (2001). An approach to the classification of algae in the new millennium. Pakistan. J of Marine Biol Pakistan. 7:233-250.

5. Hussain F, Zaidi MI \& Durrani MJ (2003). A checklist to the algae of Upper Balochistan. Pak J Pl Sci 9: 1-86.

6. Shuaib M, Ali K, Zeb U, Ahmed S, Ali S, Khan I \& Hussain F (2017). To assess the fresh water algal diversity in relation 
to water quality from river Panjkora, district Dir lower, Pakistan. Pure Appl Biol 6(2): 645-656.

7. Faridi Z (1964). Ostracods in the PlioPleistocene sediments of Gorgan and Mazanderan (Northern Iran). Iran Petrol Inst Bull 14:532-5.

8. Tiffany LH \& Britton ME (1971). The Algae of Illinois: 395 Hapner P.

9. Smith GM (1950). Fresh Water Algae of United State of America. Mc Graw Hill, New York.

10. Prescott GW (1961). Algae of the Western Great Lake Area Monograph. Michigan State University, 1-975.

11. Sheath RG \& Steinman AD (1982). A checklist of freshwater algae of the Northwest Territories, Canada. Canadian Journal of Botany 1;60(10):1964-97.

12. Khan M., Hussain $F$ \& Musharaf $S$ (2011). A fraction of fresh water algae of Kalpani stream and adjoining area of district Mardan, Pakistan. Inter J Biosci 1(3): 45-50.

13. Ali A, Shinwari ZK \& Sarim FM (2010). Contribution to the algal flora (Chlorophyta) of fresh waters of district Swat. NWFP, Pakistan. Pak J Bot 42(5): 3457-3462.

14. Leghari SM (2001). Some fresh water green filamentous algae (Chlorophyta) and Dinoboroncylindrica (Chrysophyta) from Lakes and Riverin Ponds of Sindh, Pakistan. Online J Biol Sci 1:145-149.

15. Zarina A, Shameel M \& Naz S (2010). Distribution of Freshwater Blue-Green Algae (Cyanophyta) in N. Pakistan. Int J Algae 12(3): 257-270

16. Hussain F, Leghari MK, Ahmad H, Shah SZ \& Saleem M (2010). Taxonomic study of order Chlorochocales (Volvophycota) from Peshawar valley. Int J Phycol Phycochem 6(2): 131-140.
17. Salah-Ud-Din K, Shuaib M \& Hussain F (2017). Documentation of microalgal species from selected regions of Peshawar valley, Khyber Pakhtunkhawa (KPK), Pakistan. Pure Appl Biol 6(2): 561-575

18. Ali A, Shinwari KZ \& Leghari KM (2011). The diversity of the genera of Chlorophyta in fresh waters of district Swat (N, W, F, P) Pakistan. Pakistan J Bot 43(3): 1759-1764.

19. Jang N, Shah ZS, Jan S, Junaid A, Khan K, Hussain F (2014). Local screening for Algal diversity in relation to water quality of district Swabi. Journal of Biodiversity and Environmental Sciences 5(3):9-13.

20. Aliya R, Zarina \& Shammel M (2009). Surveyof Freshwater Algae from Karachi, Pakistan. Pakistan J Bot 25 (2): 861-870.

21. Ghazala B, Hena L, Zarina A \& Shameel M (2009). Taxonomic survey of freshwater algae at the campus of BZ University of Multan, Pakistan. International $J$ of Phycology and Phycochemistry 5(1): 77-92.

22. Hussain F, Shah SZ \& Hussain Z (2016). Indexing the cyanobacterial communities of different ecological habitats of Malakand Pakistan. Pakistan $J$ of Weed Science Res 1:22(1).

23. Hussain F \& Shah SZ (2014). Direct effects of phosphates concentration on the microalgal growth in Malakand Pakistan. Pakistan J of Weed Science Res 20(2):199-206.

24. Hussain F, Leghari MK, Ahmad H, Iqbal A, Saleem M \& Laghari MY (2011). Taxonomic study of freshwater unicellular green algal species from Peshawar valley. International $\mathrm{Jl}$ of Phycology and Phycochemistry (Pakistan) 7(1): 9-12. 